Paulina Łazutka-Gawęda*

\title{
ZASADA DECENTRALIZACJI \\ A WSPÓŁDZIAŁANIE PUBLICZNOPRAWNE JEDNOSTEK SAMORZĄDU TERYTORIALNEGO - WZAJEMNE RELACJE
}

\section{Wprowadzenie}

Zasada decentralizacji to podstawowa norma ustrojowa państw demokratycznych. Posiada ona fundamentalne znaczenie dla organizacji i działania administracji publicznej, która wykonuje określone prawem zadania państwa. Ponadto charakter zasady decentralizacji można określić jako ponadczasowy i uniwersalny, ponieważ wraz z przekształceniami politycznymi, ustrojowymi i społecznymi za każdym razem ewoluuje wraz z nimi i przybiera nową postać, jak najlepiej odzwierciedlającą bieżące uwarunkowania. Słusznie zauważają M. Karcz-Kaczmarek i M. Maciejewski, że decentralizacja władzy publicznej jest obecnie procesem wręcz niezbędnym do skutecznego wykonywania zadań państwa ${ }^{1}$. Szeroki zakres zadań współczesnego państwa wymusza na nim decentralizację i sprawia, że powołanie samorządu nie jest tylko aktem dobrej woli państwa, ale środkiem umożliwiającym władzom centralnym skoncentrowanie się na spra-

Paulina Łazutka-Gawęda - doktor nauk prawnych, Uniwersytet Łódzki.

1 M. Karcz-Kaczmarek, M. Maciejewski, Glosa do wyroku Sądu Najwyższego z 6.11.2014 r., SDI 32/14, „Orzeczenia Sądów Powszechnych” 2015/7-8, s. 1189. 
wach podstawowych ${ }^{2}$. Utworzenie samorządu terytorialnego nie było zatem celem samym w sobie, lecz krokiem do lepszego zaspokojenia potrzeb społecznych ${ }^{3}$.

Celem niniejszego opracowania jest spojrzenie na tę konstytucyjną zasadę przez pryzmat współdziałania publicznoprawnego jednostek samorządu terytorialnego i próba odpowiedzi na pytanie, czy współdziałanie może istnieć bez decentralizacji i czy decentralizacja wzmacniana jest dzięki współdziałaniu. Perspektywa ta, choć jak dotąd nieopracowana w literaturze przedmiotu, wydaje się jak najbardziej uzasadniona, szczególnie wobec wciąż rosnącego znaczenia instytucji współdziałania dla efektywnie i skutecznie wykonywanych samorządowych zadań publicznych. Ponadto bardzo istotna jest uwaga sformułowana przez M. Kuleszę, który jednoznacznie podkreślił, że współcześnie decentralizacja nie polega jedynie na samodzielności w sferze imperium, dziś bowiem samorząd i decentralizacja stanowią podstawę samodzielnego zarządzania sprawami publicznymi przede wszystkim w rozumieniu gospodarczym, w systemie sieciowym, a nie hierarchicznym, przez osiąganie korzyści społecznych i gospodarczych w skali lokalnej czy regionalnej, poprzez działanie na rzecz rozwoju danej jednostki samorządu terytorialnego, organizowanie dostarczania usług publicznych, współdziałanie i zarazem konkurowanie $\mathrm{z}$ innymi samorządami, udział w rynkach ponadlokalnych i ponadregionalnych ${ }^{4}$.

\section{Charakterystyka zasad decentralizacji i współdziałania}

Zasada decentralizacji jest przedmiotem zainteresowania wielu dyscyplin naukowych, takich jak prawo, administracja, zarządzanie, so-

2 M. Stahl, E. Olejniczak-Szałowska, Samorząd terytorialny. Podstawowe zagadnienia, Warszawa 1994, s. 40.

${ }^{3}$ M. Kulesza, Zagrożenia reformy ( $w$ sprawie zadań i kompetencji samorządu terytorialnego), ST 2016/12, s. 12.

${ }^{4} \mathrm{M}$. Kulesza, O tym, ile jest decentralizacji w centralizacji, a także o osobliwych nawykach uczonych administratywistów, ST 2009/12, s. 19. 
cjologia czy politologia. Pomimo to trudno doszukać się gruntownego jej opracowania ze strony doktryny. Wszystkie obecne publikacje, za wyjątkiem monografii S. Fundowicza ${ }^{5}$, traktują zasadę decentralizacji fragmentarycznie i pobieżnie, sprowadzając główny nurt swoich zainteresowań na przedstawienie definicji tej zasady. Uwzględniając kilka publikacji, w których autorzy próbowali zbudować wyczerpującą definicję tej zasady prawnej ${ }^{6}$, można wyróżnić następujące cechy charakterystyczne decentralizacji:

1) powstają dwa poziomy administracji ukształtowane przez organ administracji przekazującej i organ administracji przyjmującej;

2) przekazaniu ulegają zadania i związane z nimi kompetencje oraz środki finansowe niezbędne do ich właściwej realizacji;

3) organ administracji przekazującej musi mieć szerszy zakres zadań od organu administracji przyjmującej, tj. dysponować takimi zadaniami, których nie ma organ przyjmujący;

4) organ administracji przyjmującej jest samodzielny w ramach przekazanych mu zadań, tj. wykonuje je we własnym imieniu i na własną odpowiedzialność;

5) po przekazaniu zadań organ administracji przekazującej traci możliwość wpływania na wykonywanie tych zadań przez organ administracji przyjmującej, tj. nie ma prawa do autoryzowania decyzji lub ich treści podejmowanych przez organ administracji przyjmującej oraz nie ma prawa do zastępowania tych decyzji swoimi. Ponadto organ administracji przekazującej nie ma prawa do dowolnego znoszenia i zastępowania organu administracji przyjmującej ${ }^{7}$;

5 S. Fundowicz, Decentralizacja administracji publicznej w Polsce, Lublin 2005.

6 J. Zimmermann, Prawo administracyjne, Warszawa 2016, s. 224; J. Boć, Decentralizacja [w:] Prawo administracyjne, red. J. Boć, Wrocław 2007, s. 234; P.A. Tusiński, Zasady wariantowe centralizacji - decentralizacji [w:] Prawo administracyjne. Część ogólna, ustrojowe prawo administracyjne, wybrane zagadnienia materialnego prawa administracyjnego, red. M. Zdyb, J. Stelmasiak, Warszawa 2016, s. 159; E. Olejniczak-Szałowska, Zasady centralizacji i decentralizacji oraz koncentracji i dekoncentracji [w:] Prawo administracyjne. Pojęcia, instytucje, zasady w teorii i orzecznictwie, red. M. Stahl, Warszawa 2016, s. 183.

7 Por. J. Bulthuis, Samenwerkung van gemeenten (Cooperation between municipalities), Alphen aan den Rijn 1957, cyt. za J. Raadschelders, Centralizacja i decentralizacja: dychotomia i kontinuum, ST 1994/6, s. 4. 
6) samodzielność organu administracji przyjmującej jest względna, tj. jej granice wyznaczone są przez określone normą prawną środki nadzoru. Samodzielność ta jest chroniona prawem, ponieważ istnieją środki prawne ją zabezpieczające;

7) pomiędzy organem administracji przekazującej i przyjmującej nie występuje hierarchiczne podporządkowanie, nie ma więzi kierownictwa, zależności służbowej lub osobowej.

Tak rozumiana decentralizacja jest zasadą ustrojową, która statuuje istnienie i funkcjonowanie samorządu terytorialnego. Ustrojodawca umieścił ją w art. 15 ust. 1 Konstytucji RP, stanowiąc, że ustrój terytorialny Rzeczypospolitej Polskiej zapewnia decentralizację władzy publicznej. J. Boć nazwał uregulowanie art. 15 Konstytucji RP historycznym oczekiwaniem ${ }^{9}$, co podkreśla znaczenie i nadzieje pokładane w tej zasadzie. Zasada decentralizacji współistnieje z zasadą centralizacji. Obie one mają charakter relatywny, tj. jeżeli jedna $\mathrm{z}$ nich realizowana jest $\mathrm{w}$ większym stopniu, to druga odpowiednio w stopniu mniejszym i odwrotnie ${ }^{10}$. Efektem jest istnienie w Polsce dualistycznego systemu administracji publicznej, administracji rządowej opartej na zasadzie centralizacji oraz administracji samorządowej (samorządu terytorialnego) opartej na zasadzie decentralizacji. Zdaniem A. Wiktorowskiej decentralizacja władzy publicznej wskazana w Konstytucji RP oznacza przeniesienie władztwa (imperium) na podmioty odrębne od państwa jako osoby prawne prawa publicznego, np. gminy, i wyposażenie tych podmiotów w kompetencje władcze oraz uwolnienie ich $\mathrm{z}$ systemu hierarchicznego podporządkowania ${ }^{11}$. P. Sarnecki trafnie zauważa, że art. 15 ust. 1 Konstytucji RP nie wskazuje na docelowy stan decentralizacji ${ }^{12}$. Stanowisko autora potwierdza orzecznictwo TK. Trybunał uznał bowiem, że pojęcie decentraliza-

\footnotetext{
${ }^{8}$ J. Starościak, Decentralizacji administracji publicznej, Warszawa 1960, s. 11-12.

9 J. Boć, Pięć podstawowych problemów samorządu terytorialnego [w:] Studia nad samorzadem terytorialnym, red. A. Błaś, Wrocław 2002, s. 39.

10 E. Olejniczak-Szałowska, Zasady... [w:] Prawo..., red. M. Stahl, s. 182.

11 A. Wiktorowska, Prawne determinanty samodzielności gminy. Zagadnienia administracyjnoprawne, Warszawa 2002, s. 55.

12 P. Sarnecki, Komentarz do art. 15 Konstytucji RP, Teza 3 [w:] Konstytucja Rzeczypospolitej Polskiej. Komentarz, red. L. Garlicki, M. Zubik, t. 1, Wstęp, art. 1-29, Warszawa 2016.
} 
cji oznacza proces stałego poszerzania uprawnień jednostek władzy publicznej niższego stopnia w drodze przekazywania im zadań, kompetencji oraz niezbędnych środków. Decentralizacja, o której stanowi Konstytucja RP, nie jest jednorazowym przedsięwzięciem organizacyjnym, lecz trwałą cechą kultury politycznej państwa zbudowanej na właściwych rozwiązaniach ustawowych, zgodnych z konstytucyjnymi zasadami ustroju Rzeczypospolitej. Granicami decentralizacji są wyznaczone przez konsekwencje ustrojowe zasady, zgodnie z którymi Rzeczpospolita jest dobrem wspólnym wszystkich obywateli, co oznacza konieczność utrzymania równowagi między potrzebami i interesami lokalnymi znajdującymi wyraz w kompetencjach przyznanych społecznościom lokalnym a potrzebami i interesami o charakterze ponadlokalnym. Granice decentralizacji wynikają także z obywatelskiego prawa do dobrej administracji mającego mocne oparcie w postanowieniach Karty Praw Podstawowych UE. Pojęcie decentralizacji jest pojęciem wielowymiarowym, obejmującym z jednej strony zakaz skupiania władzy, z drugiej zaś nakaz poszukiwania najbardziej efektywnych rozwiązań strukturalnych ${ }^{13}$.

Zasada decentralizacji nie jest zasadą absolutną, jej granice wyznacza art. 3 Konstytucji RP, który określa Rzeczpospolitą Polską jako państwo unitarne. Należy zaznaczyć wszak, że zasada jednolitości nie stoi w sprzeczności z zasadą decentralizacji i funkcjonowaniem w ramach państwa samorządu terytorialnego. Słusznie zauważa E. Olejniczak-Szałowska, że decentralizacja nie wyklucza takich rozwiązań ustrojowych w dziedzinie samorządu terytorialnego, które polegają na wyłączeniu pewnych spraw z kompetencji organów lokalnych i przekazaniu ich innym organom władzy. Wyłączenie to powinno być jednak dokonane w zakresie określonym prawem, a zatem w zgodzie z Konstytucją RP, w drodze ustawy, przy poszanowaniu wymagań racjonalności ${ }^{14}$.

Przykładem możliwości wyłączania pewnych spraw z kompetencji jednostek samorządu terytorialnego i przekazywania ich bądź pomiędzy

${ }_{13}$ Wyrok TK z 18.02.2003 r., K 24/02, OTK-A 2003/2, poz. 11.

14 E. Olejniczak-Szałowska, Zasady... [w:] Prawo..., red. M. Stahl, s. 185. 
tymi jednostkami, bądź też przekazywania ich na rzecz odrębnych podmiotów jest instytucja współdziałania. W ujęciu prawnym współdziałanie zachodzi wówczas, gdy pewien problem społeczny, kulturalny lub gospodarczy nie jest rozwiązany przez jeden podmiot administracji. Termin ten traktowany jest jako synonim współpracy, wspólnego działania. Konkretną potrzebę współdziałania należy rozpatrywać przez pryzmat celu oraz efektywności i użyteczności takiego działania.

Początki współdziałania w Polsce sięgają dwudziestolecia międzywojennego, kiedy to odrodzone państwo polskie rozpoczęło kształtowanie swojej administracji publicznej. Wraz z tworzeniem samorządu terytorialnego dostrzeżono potrzebę wprowadzenia możliwości współpracy pojedynczych jednostek samorządu terytorialnego. Wzorowano się w tym przedmiocie na postanowieniach pruskiej ustawy o związkach celowych z $1911 \mathrm{r} .{ }^{15}$, której nowoczesne i dalekowzroczne rozwiązania stały się podwaliną dla dwóch podstawowych polskich form współpracy publicznoprawnej, tj. związku celowego i porozumienia publicznoprawnego. Wprowadzenie takich rozwiązań prawnych było możliwe dzięki oparciu ustroju Rzeczypospolitej Polskiej na zasadzie szerokiego samorządu terytorialnego, którego przedstawicielom, zgodnie z art. 3 Konstytucji Marcowej, miał zostać przekazany właściwy zakres ustawodawstwa, zwłaszcza z dziedziny administracji, kultury i gospodarstwa ${ }^{16}$. Wraz z biegiem czasu, przemianami politycznymi lat 30 . XX w. oraz nową rzeczywistością powojenną samorząd terytorialny stawał się coraz mniej popularny, dostrzegano w nim zagrożenie dla nowej władzy. Wyrazem tego był przede wszystkim art. 4 ust. 3 Konstytucji Kwietniowej, który w przeciwieństwie do Konstytucji Marcowej nie opierał już ustroju państwa na instytucji samorządu terytorialnego, a jedynie wskazywał, że zostanie powołany samorząd terytorialny i gospodarczy do udziału w wykonywaniu zadań życia zbiorowego ${ }^{17}$. Była to bez wątpienia ogromna zmiana jakościowa, która doprowadziła do marginalizacji samorządu

15 Zweckverbandsgesetz v. 19. Juli 1911, GS, s. 115.

${ }^{16}$ Ustawa z 17.03.1921 r. - Konstytucja Rzeczypospolitej Polskiej (Dz.U. Nr 47, poz. 267).

17 Ustawa Konstytucyjna z 23.04.1935 r. (Dz.U. Nr 30, poz. 227). 
terytorialnego. Efektem tego był szereg reform wprowadzanych na początku dekretem z 23.11.1944 r. o organizacji i zakresie działania samorządu terytorialnego ${ }^{18}$, a potem ustawą z 20.03.1950 r. o terenowych organach jednolitej władzy państwowej ${ }^{19}$. To właśnie ustawa z 1950 r. zniosła zupełnie samorząd terytorialny, zastępując go systemem rad narodowych. Wraz z rezygnacją z samorządu terytorialnego zrezygnowano także $\mathrm{z}$ instytucji współdziałania. Uznano bowiem, że współdziałanie będzie nieprzydatne dla celów kooperacji czy koordynacji w systemie rad narodowych. Obawiano się również, że tworzenie związków celowych może doprowadzić do ograniczenia znaczenia rad narodowych ${ }^{20}$. Nowa sytuacja polityczno-prawna określona została mianem centralizmu demokratycznego. Ten krótki rys historyczny rozwoju współdziałania w Polsce ma za zadanie pokazać pewną prawidłowość, tj. wraz z ograniczaniem zasady decentralizacji dochodzi do ograniczenia zasady współdziałania. W zupełnym centralizmie nie ma miejsca na współdziałanie. Może się ono rozwijać wyłącznie w systemach w pełni zdecentralizowanych, gdzie jednostki samorządu terytorialnego traktowane są przez państwo (administrację państwową) jak partnerzy, a nie jak konkurencja.

$\mathrm{Na}$ fali przemian ustrojowych, jakie nastąpiły w Polsce po 1989 r., doszło do przywrócenia zasady decentralizacji i odbudowy samorządu terytorialnego. Wraz z tymi wydarzeniami powrócono również do dobrych tradycji współdziałania jednostek samorządu terytorialnego. Zasada współdziałania została umieszczona przez ustrojodawcę w preambule Konstytucji RP. Opierając ustrój państwa na zasadzie decentralizacji, uznano ją niejako za naczelną wartość tego ustroju. Analogicznie do zasady decentralizacji, również współdziałanie stało się fundamentem demokratycznego państwa prawnego $^{21}$. I. Skrzydło-Niżnik słusznie uznaje, że jest to zasada kierunkowa, kwalifikowana jako zasada obowiązku działania administracji publicznej, a nie obowiązek nałożony na podmioty ad-

${ }_{18}$ Dz.U. Nr 14, poz. 74.

19 Dz.U. Nr 14, poz. 130 ze zm.

${ }^{20}$ M. Ofiarska, Formy publicznoprawne współdziałania jednostek samorządu terytorialnego, Warszawa 2008, s. 243.

${ }^{21}$ Por. wyrok TK z 11.05.2005 r., K 18/04, OTK-A 2005/5, poz. 49. 
ministracji publicznej ${ }^{22}$. Od tych wydarzeń minęło już ponad 25 lat. Przez ten czas zmieniła się zupełnie pozycja Polski na arenie międzynarodowej. Przez członkostwo w NATO czy w Unii Europejskiej zostaliśmy jednoznacznie zaklasyfikowani do kręgu państw demokratycznych. Ponadto rzetelna praca poszczególnych samorządów pozwoliła na okrzepnięcie całego systemu samorządu terytorialnego i dostrzeżenie ogromnego potencjału, jaki tkwi w gminach, powiatach, województwach samorządowych. Potencjał ten był wydobywany z samorządów i powiększany między innymi dzięki zasadzie współdziałania.

\section{Zależności pomiędzy zasadą decentralizacji i zasadą współdziałania}

Pomiędzy obiema zasadami można dostrzec podobieństwa i zależności warunkujące całkowitą niemożność funkcjonowania współdziałania bez decentralizacji. Decentralizacja zaś bez współdziałania jest teoretycznie możliwa, choć co istotne, taki stan rzeczy znacznie osłabia jej potencjał. Rozpatrując współistnienie tych dwóch zasad, można wskazać na następujące ich podobieństwa i zależności:

1. Ciągłość i trwałość realizacji celów założonych przez prawodawcę $^{23}$

Administracja, jej ustrój, organizacja i formy działania cały czas podlegają dynamicznym zmianom, wychodząc naprzeciw oczekiwaniom społecznym i przemianom polityczno-gospodarczym. W żadnym razie nie można określić tego układu jako statyczny. Wraz z tymi przemianami ewolucji podlegają główne zasady i instytucje prawne. Zmiany te nie oznaczają jednak niepewności ustroju państwa. Zarówno instytucja współdziałania, jak i decentralizacja cechują się względną ciągłością i trwałością obranych celów. Ciągłość ta nie jest jednak synonimem stagnacji. Odnosi

${ }^{22}$ I. Skrzydło-Niżnik, Model ustroju samorządu terytorialnego w Polsce na tle zagadnień ustrojowego prawa administracyjnego, Kraków 2007, s. 530-531.

${ }^{23}$ Zależności 1, 2, 3, 5 zostały opracowane w oparciu o artykuł E. Olejniczak-Szałowskiej - E. Olejniczak-Szałowska, Współdziałanie państwowych jednostek organizacyjnych jako instytucja prawna, „Organizacja - Metody - Technika” 1987/1. 
się ona do podstaw prawnych, trwałości zasad ustrojowych państwa, pewnej kultury prawnej będącej wyrazem bezpieczeństwa obywateli. Nie oznacza ona przecież braku możliwości zmian decyzyjnych podejmowanych w przedmiocie współdziałania. Trwałym i niezmiennym celem jest dobro publiczne. Aby je osiągnąć, władze - zarówno centralne, jak i samorządowe - mogą czynić wszystko to, co jest dopuszczalne prawnie, dowolnie modyfikować i wykorzystać przewidziane prawem instytucje, kierując się dobrem publicznym. J. Boć zwraca uwagę, że poziom tej ciągłości i niezmienności może przyjmować różne nasilenie, na które wpływ ma prawo oraz zmieniające się tendencje w praktyce ${ }^{24}$.

\section{Istnienie podstawy prawnej dla ich podjęcia}

Współdziałanie, tak jak i decentralizacja, możliwe jest tylko w oparciu o konkretną normę prawną. W polskim porządku prawnym niewątpliwie główne znaczenie dla zasady decentralizacji ma art. 15 ust. 1 oraz art. 172 Konstytucji RP, który dopuszcza współdziałanie jednostek samorządu terytorialnego. Obie zasady mają zatem umocowanie konstytucyjne. Konkretyzacja tych norm następuje w samorządowych ustawach ustrojowych (u.s.g., u.s.p. oraz u.s.w.), które statuują funkcjonowanie poszczególnych jednostek samorządu terytorialnego oraz warunki współpracy pomiędzy nimi.

3. Cel obu zasad sformułowany jest w prawie obowiązującym, przy czym cele własne uczestników układu stanowią elementy owego celu nadrzędnego

Główny cel współdziałania jednostek samorządu terytorialnego, czyli wspólne wykonywanie zadań publicznych, został wskazany w u.s.g. i u.s.p. w rozdziale 7 , a w u.s.w. w rozdziale 6 , natomiast celem decentralizacji $\mathrm{w}$ formie samorządu terytorialnego jest zgodnie $\mathrm{z}$ art. 15 ust. 2 Konstytucji RP poprzez uwzględnienie więzi społecznych, gospodarczych lub kulturowych zapewnienie jednostkom terytorialnym zdolności wykonywania zadań publicznych. W obu przypadkach kluczowe znaczenie ma właściwe, racjonalne i efektywne wykonywanie zadań publicznych, które zapewni jednocześnie maksymalną użyteczność po stro-

${ }^{24}$ J. Boć, Decentralizacja... [w:] Prawo..., red. J. Boć, s. 235. 
nie wspólnoty lokalnej, zatem zarówno działania decentralizacyjne, jak i współdziałanie służą optymalizacji realizacji zadań publicznych.

4. W ramach współdziałania i decentralizacji przekazaniu ulegają zadania i związane $z$ nimi kompetencje oraz środki finansowe niezbędne do ich właściwej realizacji

W obu przypadkach dochodzi po przekazania zadań publicznych. Bez względu na to, czy rozpatrywana jest forma publicznoprawnego współdziałania w ramach związku celowego, czy też na podstawie porozumienia publicznoprawnego istnieją dwa podmioty, podmiot przekazujący zadania, odpowiednio jednostki samorządu terytorialnego, które powołują związek celowy, lub też jednostka lub jednostki przekazujące zadania w drodze porozumienia oraz podmiot przyjmujący, tj. związek celowy lub jednostka samorządu terytorialnego przejmująca zadania w oparciu o podpisane porozumienie. Aby zadania te mogły być we właściwy sposób realizowane, podmioty przekazujące wraz z przesunięciem zadań muszą powierzyć związane z nimi kompetencje, w tym kompetencje władcze i prawotwórcze oraz odpowiednie środki finansowe.

Analogiczna sytuacja występuje w przypadku decentralizacji $\mathrm{w}$ formie samorządu terytorialnego. Po stronie podmiotu przekazującego jest administracja państwowa, która $\mathrm{z}$ własnego zakresu działania wyodrębnia pule zadań publicznych, które następnie przekazuje na rzecz poszczególnych jednostek samorządu terytorialnego (gmin, powiatów, województw), które stają się podmiotem przyjmującym. Wraz z tym przekazaniem przesunięciu ulegają kompetencje władcze, prawotwórcze i środki finansowe.

5. Brak jest organizacyjnego podporządkowania między podmiotami zmierzającymi do osiągnięcia wspólnego celu. Pozycja podmiotów zgrupowanych w układzie współdziałania jest równorzędna

Równorzędność podmiotów współdziałania jest cechą immanentną tej instytucji prawnej. Jest to symbol równorzędności wszystkich partnerów współpracy oraz równorzędności interesów, jakie oni reprezentują. Chodzi tu o reprezentowanie przez każdą stronę wyłącznie interesów publicznych wynikających ze sfery obowiąz- 
ków działania administracji publicznej ${ }^{25}$. Brak hierarchicznego podporządkowania, więzi kierownictwa, zależności służbowych i osobowych występuje również w przypadku decentralizacji.

Przedstawiając występujące pomiędzy obiema zasadami podobieństwa i zależności, należy zwrócić uwagę na podstawową różnicę, którą jest przymiot samodzielności. Wyłącznie układ administracji zdecentralizowanej cechuje się samodzielnością, ponieważ, aby zasada decentralizacji mogła prawidłowo funkcjonować, potrzebny jest brak skrępowania w działaniach niższych szczebli przez organ wyższego stopnia ${ }^{26}$. Instytucja współdziałania, choć jest wyrazem samodzielności przyznanej jednostkom samorządu terytorialnego, to takiej cechy nie posiada. Podmioty współdziałania nie są samodzielne, zależne są one zarówno od tworzących je jednostek samorządu terytorialnego, jak i od decyzji kształtowanych przez ustawodawcę.

\section{Zagrożenia dla zasady decentralizacji i współdziałania}

Ostatnie 25 lat działania tego tandemu, pomimo licznych podobieństw i sukcesów, uwidoczniło również szereg problemów. Perspektywa czasu zobowiązuje niejako do dostrzeżenia tych problemów i zagrożeń, zarówno dla zasady decentralizacji i zasady współdziałania rozpatrywanych odrębnie, jak i dla ich współistnienia. Nieodosobnione są głosy podnoszone w doktrynie, że samorząd terytorialny, przy całym pragmatyzmie swojego działania i zajmowaniu się na co dzień konkretnymi sprawami mieszkańców, posiada głęboki sens i wymiar ustrojowy. Opiera się on na spójnym systemie wartości ${ }^{27}$. System tych wartości jest

${ }^{25}$ J. Starościak, Prawne formy i metody działania administracji [w:] System Prawa Administracyjnego, red. T. Rabska, J. Łętowski, t. 3, Wrocław 1978, s. 47.

${ }^{26}$ A. Wiktorowicz, Samorząd terytorialny $w$ świetle art. 15 Konstytucji RP [w:] Struktury administracji publicznej. Metody, ogniwa, więzi, red. A. Mezglewski, t. 2, Rzeszów 2016, s. 331.

27 I. Lipowicz, Prawne problemy samorzadu terytorialnego z perspektywy 25-lecia jego funkcjonowania - ujęcie aksjologiczne [w:] Prawne problemy samorządu terytorialnego z perspektywy 25-lecia jego funkcjonowania, red. B. Jaworska-Dębska, R. Budzisz, Warszawa 2016, s. 3. 
zakorzeniony historycznie. Poprzez istnienie pewnego kanonu wartości uniwersalnych i analizę prawa przez pryzmat historycznego rozwoju można dostrzec ponadczasowy ich wymiar ${ }^{28}$. Wartościami tymi bez wątpienia jest właśnie zasada decentralizacji, dająca podstawę prawną dla istnienia samorządu terytorialnego, i zasada współdziałania, która w odpowiedni sposób wykorzystana może doprowadzić do rozwoju i zwiększenia potencjału poszczególnych jednostek samorządu terytorialnego.

Jak wskazano powyżej, 25-letnia perspektywa funkcjonowania samorządu terytorialnego w Polsce pozwala dostrzec wciąż nawarstwiające się zagrożenia prawne dla tych dwóch zasad. W odniesieniu do zasady decentralizacji coraz bardziej ważki jest problem stopniowej centralizacji początkowo zdecentralizowanych zadań. Sytuacja ta budzi wątpliwości prawne, jak bowiem słusznie wskazywał J. Boć, Konstytucja RP, utrzymując podział na zadania własne i zlecone, daje możliwość zlecania zadań na rzecz jednostek samorządu terytorialnego i nie przewiduje możliwości odwrotnej. Oznacza to, że można uszczuplać zadania i kompetencje administracji rządowej, nie można zaś ich odejmować administracji samorządowej ${ }^{29}$. Zdaniem J. Korczaka w obliczu przyjętej w Konstytucji RP zasady decentralizacji wszelkie procesy recentralizacji są naruszeniem Konstytucji RP i tak należy ocenić regulacje ustawowe odbierające jednostkom samorządu terytorialnego przyznane im wcześniej zadania lub w istotny sposób ograniczające samodzielne ich wykonywanie ${ }^{30}$.

Obecna praktyka prawna pokazuje jednak zupełnie odmienną rzeczywistość. Przykłady wprowadzające rozwiązania centralizacyjne są bardzo liczne. Dla ich zobrazowania można powołać się na następujące praktyki.

${ }^{28}$ Por. J. Jeżewski, Wartość poznawcza dawnych poglądów nauki prawa administracyjnego w projekcji współczesnego sposobu myślenia [w:] Wartości w prawie administracyjnym, red. J. Zimmermann, Warszawa 2015, s. 135-142.

${ }_{29}$ J. Boć, Pięć... [w:] Studia..., red. A. Błaś, s. 38-39.

${ }^{30}$ J. Korczak, Decentralizacja i recentralizacja $w$ administracji publicznej na przykładzie zadań własnych i zleconych jednostek samorzadu terytorialnego [w:] Aktualne problemy funkcjonowania samorzadu terytorialnego, red. E. Ura, E. Feret, S. Pieprzny, Rzeszów-Sandomierz 2017, s. 32. 
Po pierwsze, zmiany wprowadzane w prawie oświatowym. Zgodnie z prawem oświatowym rady gmin w celu ustalenia sieci prowadzonych przez siebie publicznych przedszkoli, oddziałów przedszkolnych i szkół potrzebują pozytywnej opinii kuratora oświaty o zgodności tej sieci z warunkami wskazanymi w ustawie ${ }^{31}$. W rzeczywistości nie jest to opinia, tylko zgoda warunkująca utworzenie takiej sieci lub też odmawiająca możliwości takiego działania. Kompetencje samorządu zostały zatem ograniczone i ściśle powiązane z decyzją kuratora oświaty, który jest niewątpliwie organem zespolonej administracji rządowej.

Po drugie, warto zwrócić uwagę na zmiany wprowadzone do Prawa wodnego. Wydawane dotychczas przez organy samorządu terytorialnego zgody wodnoprawne na skutek nowelizacji Prawa wodnego $^{32}$ zostały przeniesione do kompetencji administracji rządowej. Zgodnie z art. 397 tej ustawy organem właściwym w sprawie zgód wodnoprawnych są właściwe organy Wód Polskich, zaś Prezes Wód Polskich, zgodnie z art. 14 ustawy, jest po ministrze właściwym do spraw gospodarki wodnej oraz ministrze do spraw żeglugi śródlądowej organem właściwym w sprawie gospodarowania wodami. Przywołane postanowienia ustawy nie pozostawiają wątpliwości co do zupełnego pozbawienia kompetencji organów jednostek samorządu terytorialnego w zakresie gospodarowania wodami i przeniesienie ich na specjalnie utworzony w tym celu organ administracji rządowej.

Po trzecie, jaskrawym przykładem działań centralizacyjnych w obrębie samorządu terytorialnego jest ustawa z 1.04.2016 r. o zakazie propagowania komunizmu lub innego ustroju totalitarnego przez nazwy jednostek organizacyjnych, jednostek pomocniczych gminy, budowli, obiektów i urządzeń użyteczności publicznej oraz pomniki³. Zgodnie z postanowieniami tego aktu prawnego nazwy jednostek organizacyj-

${ }^{31}$ Por. m.in. art. 32 ust. 1 i 2 ustawy z 14.12.2016 r. - Prawo oświatowe (Dz.U. z 2018 r. poz. 996 ze zm.).

${ }^{32}$ Ustawa z 20.07.2017 r. - Prawo wodne (Dz.U. z 2017 r. poz. 1566 ze zm.).

${ }_{33}$ Dz.U. z 2018 r. poz. 1103. 
nych, jednostek pomocniczych gminy, budowli, obiektów i urządzeń użyteczności publicznej, w tym dróg, ulic, mostów i placów, nadawane przez jednostki samorządu terytorialnego nie mogą upamiętniać osób, organizacji, wydarzeń lub dat symbolizujących komunizm lub inny ustrój totalitarny ani w inny sposób takiego ustroju propagować. W sytuacji gdyby do tego doszło, wojewoda zobowiązany jest do wydania rozstrzygnięcia nadzorczego. Jeżeli jednostka samorządu terytorialnego nie zastosuje się do niego, wojewoda stwierdza nieważność takiej uchwały i wydaje zarządzenie zastępcze, które podlega wykonaniu począwszy od dnia jego wejścia w życie. Jednostce samorządu terytorialnego przysługuje skarga do sądu administracyjnego na takie zarządzenie, ale jedynie wówczas, gdy brak możliwości wykonania obowiązku wskazanego w zarządzeniu wynikał z przyczyn niezależnych od tej jednostki. Tak skonstruowany zakres wydawania przez wojewodę zarządzenia zastępczego jest niewątpliwie rozszerzeniem o charakterze przedmiotowym zarządzenia zastępczego wskazanego w art. 98a u.s.g. Ponadto jest to przejaw ograniczania prawnie chronionej samodzielności jednostki samorządu terytorialnego, gdyż możliwość zaskarżenia takiego zarządzenia do sądu administracyjnego możliwa jest jedynie pod warunkiem spełnienia przesłanki wskazanej w ustawie. Innymi słowy przywołana ustawa jest kolejnym przykładem na działania centralizacyjne w ramach samorządu terytorialnego. Ustawodawca zakłada bowiem, że jednostka samorządu terytorialnego nie jest w stanie samodzielnie realizować swoich zadań i niezbędna jest jej pomoc ze strony administracji rządowej. Takie posunięcia ze strony ustawodawcy są przejawem deprecjonowania znaczenia i roli w państwie samorządu terytorialnego i zasady decentralizacji, której jest on odzwierciedleniem. Choć od wielu lat w doktrynie podnosi się, że samorząd terytorialny obarczony jest bardzo dużą ilością różnorodnych zadań, z którymi wiąże się niedostateczne dofinansowanie ze strony państwa, dziś argument ten staje się wymówką pozwalającą na uchwalenie ustaw z elementami typowo centralistycznymi. Jest to zatem kolejny przykład bagatelizowania konkretnych problemów samorządów i próba ich opacznego rozwiązywania, która jest krokiem w kierunku zupełnego zmarginalizowania roli samorządu terytorialnego w państwie. Administracji rządowej, która powinna poświęcić się wykonywaniu zadań ogólno- 
państwowych, przypisuje się zaś wyjątkową profesjonalizację i szeroką wiedzę również w zakresie zadań lokalnych, co bez wątpienia jest zaburzeniem dualistycznego systemu administracji państwowej.

Przemiany prawne i społeczne ingerują również w działanie zasady współdziałania, która dziś podobnie do zasady decentralizacji jest marginalizowana i której pełen potencjał nie jest wykorzystywany. Wśród głównych zagrożeń dla zasady współdziałania można wskazać m.in. brak reakcji ustawodawcy na płynące od wielu lat sugestie doktryny co do oczekiwanych zmian w przepisach prawnych dotyczących współpracy jednostek samorządu terytorialnego. Obecna regulacja prawna jest w tym zakresie cząstkowa, rozproszona w wielu ustawach, często również niespójna. Praktyka posługiwania się tymi przepisami wzbudza w niektórych kwestiach uzasadnione wątpliwości, które obarczają podmioty uprawnione do współdziałania. W tym stanie rzeczy brak transparentności przepisów i ich niedookreśloność obniżają zainteresowanie jednostek samorządu terytorialnego współdziałaniem. Zarówno orzecznictwo, jak i doktryna nie są już w stanie wyeliminować tych barier. Działania ustawodawcy idą jednak w zupełnie innym kierunku. Podejmowane są działania, które pozornie mają na celu poprawę sytuacji współdziałania w polskim samorządzie, są też niewątpliwie odpowiedzią na potrzeby zgłaszane przez społeczeństwo, jednak brak właściwej analizy proponowanych zmian, ich wpływu na obecnie obowiązujące przepisy oraz brak właściwej organizacji i zgromadzenia odpowiedniego potencjału politycznego powodują, że wywołują one skutki odwrotne od pierwotnie zakładanych. Najbardziej wymownym przykładem tej sytuacji jest nieobowiązująca już ustawa o związkach metropolitalnych ${ }^{34}$, która miała być remedium na wszelkie problemy polskich metropolii, zupełnie pominiętych przy konstruowaniu rozwiązań prawnych po $1989 \mathrm{r}$. Ustawa wprowadzała do polskiego porządku prawnego nową formę współdziała, tj. związek metropolitalny, którego istnienie w ramach ustalonego obszaru metropolitalnego miało rozwiązywać kompleksowo wszelkie problemy dużych miast i ich otoczenia. Ustawa od samego początku wzbudzała kontrowersje, była także określana jako źle

${ }^{34}$ Ustawa z 9.10.2015 r. o związkach metropolitalnych (Dz.U. poz. 1890 ze zm.). 
i pobieżnie przygotowana. Ostatecznie po półtorarocznym obowiązywaniu została uchylona, w efekcie czego nadal nie ma w Polsce odpowiednich regulacji prawnych dotyczących funkcjonowania samorządów dużych miast. Wyjątkiem jest ustawa z 9.03.2017 r. o związku metropolitalnym w województwie śląskim ${ }^{35}$, która uchyliła obowiązywanie ustawy z $2015 \mathrm{r}$. Ustawa określa zasady powołania związku metropolitalnego, który jest zrzeszeniem gmin województwa śląskiego, charakteryzujących się istnieniem silnych powiązań funkcjonalnych oraz zaawansowaniem procesów urbanizacyjnych, położonych na obszarze spójnym pod względem przestrzennym, który zamieszkuje co najmniej 2000000 mieszkańców. W skład tego związku wchodzi również miasto na prawach powiatu Katowice. Obecnie zostało już wydane rozporządzenie wykonawcze do ustawy dotyczące utworzenia w województwie śląskim związku metropolitalnego pod nazwą "Górnośląsko-Zagłębiowska Metropolia" ${ }^{36}$. Są to bez wątpienia początki, które trudno oceniać pod względem efektywności i korzystności działania dla regionu i jego mieszkańców, jednak w perspektywie braku odpowiednich regulacji prawnych dla całego obszaru Polski może to być ciekawe działanie o charakterze pilotażowym, którego sukces może zaowocować w perspektywie kolejnych lat konkretnymi rozwiązaniami również dla innych dużych polskich miast.

\section{Zakończenie}

Obecne realia prawne, polityczne i społeczne są ogromnym wyzwaniem dla należytego działania zarówno zasady decentralizacji, jak i zasady współdziałania. Nieodosobnione są zaprezentowane w głównej części opracowania inicjatywy będące ogromnym zagrożeniem dla istnienia tych zasad w ich kształcie konstytucyjnym oraz ich należytego funkcjonowania. Bez wątpienia zasada decentralizacji i zasada współdziałania to takie zasady ustrojowe państwa polskiego, które

${ }^{35}$ Dz.U. poz. 730 .

${ }^{36}$ Rozporządzenie Rady Ministrów z 26.06.2017 r. w sprawie utworzenia w województwie śląskim związku metropolitalnego pod nazwą "Górnośląsko-Zagłębiowska Metropolia" (Dz.U. poz. 1290). 
statuują istnienie samorządu terytorialnego oraz jego efektywne działanie. Jako zasady wręcz naczelne współistnieją niczym nierozerwalny tandem, współdziałanie bez decentralizacji byłoby bowiem jedynie pustym hasłem. Również decentralizacja w formie samorządu terytorialnego bez współdziałania pozbawiona jest pełnej efektywności i sprawności działania przy wykonywaniu zadań publicznych.

\section{Bibliografia:}

Boć J., Decentralizacja [w:] Prawo administracyjne, red. J. Boć, Wrocław 2007 Boć J., Pięć podstawowych problemów samorzadu terytorialnego [w:] Studia nad samorządem terytorialnym, red. A. Błaś, Wrocław 2002

Bulthuis J., Samenwerkung van gemeenten (Cooperation between municipalities), Alphen aan den Rijn 1957

Fundowicz S., Decentralizacja administracji publicznej w Polsce, Lublin 2005

Jeżewski J., Wartość poznawcza dawnych pogladów nauki prawa administracyjnego w projekcji współczesnego sposobu myślenia [w:] Wartości w prawie administracyjnym, red. J. Zimmermann, Warszawa 2015

Karcz-Kaczmarek M., Maciejewski M., Glosa do wyroku Sadu Najwyższego $z$ 6.11.2014 r., SDI 32/14, „Orzeczenia Sądów Powszechnych” 2015/7-8

Korczak J., Decentralizacja i recentralizacja w administracji publicznej na przykładzie zadań własnych i zleconych jednostek samorzadu terytorialnego [w:] Aktualne problemy funkcjonowania samorzadu terytorialnego, red. E. Ura, E. Feret, S. Pieprzny, Sandomierz-Rzeszów 2017

Kulesza M., O tym, ile jest decentralizacji w centralizacji, a także o osobliwych nawykach uczonych administratywistów, ST 2009/12

Kulesza M., Zagrożenia reformy (w sprawie zadań i kompetencji samorządu terytorialnego), ST 2016/12

Lipowicz I., Prawne problemy samorzadu terytorialnego z perspektywy 25-lecia jego funkcjonowania - ujęcie aksjologiczne [w:] Prawne problemy samorzadu terytorialnego z perspektywy 25-lecia jego funkcjonowania, red. B. Jaworska-Dębska, R. Budzisz, Warszawa 2016

Ofiarska M., Formy publicznoprawne współdziałania jednostek samorzadu terytorialnego, Warszawa 2008

Olejniczak-Szałowska E., Współdziałanie państwowych jednostek organizacyjnych jako instytucja prawna, „Organizacja - Metody - Technika” 1987/1 
Olejniczak-Szałowska E., Zasady centralizacji i decentralizacji oraz koncentracji i dekoncentracji [w:] Prawo administracyjne. Pojęcia, instytucje, zasady w teorii i orzecznictwie, red. M. Stahl, Warszawa 2016

Raadschelders J., Centralizacja i decentralizacja: dychotomia i kontinuum, ST 1994/6; Sarnecki P., Komentarz do art. 15 Konstytucji RP, Teza 3 [w:] Konstytucja Rzeczypospolitej Polskiej. Komentarz, t. 1, Wstęp, art. 1-29, red. L. Garlicki, M. Zubik, Warszawa 2016

Skrzydło-Niżnik I., Model ustroju samorzadu terytorialnego w Polsce na tle zagadnień ustrojowego prawa administracyjnego, Kraków 2007

Stahl M., Olejniczak-Szałowska E., Samorząd terytorialny. Podstawowe zagadnienia, Warszawa 1994

Starościak J., Decentralizacji administracji publicznej, Warszawa 1960

Starościak J., Prawne formy i metody działania administracji [w:] System Prawa Administracyjnego, red. T. Rabska, J. Łętowski, t. 3, Wrocław 1978

Tusiński P.A., Zasady wariantowe centralizacji - decentralizacji [w:] Prawo administracyjne. Część ogólna, ustrojowe prawo administracyjne, wybrane zagadnienia materialnego prawa administracyjnego, red. M. Zdyb, J. Stelmasiak, Warszawa 2016

Wiktorowicz A., Samorząd terytorialny w świetle art. 15 Konstytucji RP [w:] Struktury administracji publicznej. Metody, ogniwa, więzi, red. A. Mezglewski, t. 2, Rzeszów 2016

Wiktorowska A., Prawne determinanty samodzielności gminy. Zagadnienia administracyjnoprawne, Warszawa 2002

Zimmermann J., Prawo administracyjne, Warszawa 2016 